\title{
Pharmacokinetics and distribution of dietary tributyltin compared to those of methylmercury in the American plaice Hippoglossoides platessoides
}

\author{
Claude Rouleau ${ }^{1, *}$, Charles Gobeil ${ }^{1}$, Hans Tjälve ${ }^{2}$ \\ ${ }^{1}$ Department of Fisheries and Oceans, Maurice Lamontagne Institute, PO Box 1000, Mont-Joli, Quebec G5H 3Z4, Canada \\ ${ }^{z}$ Swedish University of Agricultural Sciences, Faculty of Veterinary Medicine, Department of Pharmacology and Toxicology, \\ Biomedicum Box 573, S-751 23 Uppsala, Sweden
}

\begin{abstract}
Pharmacokinetics and distribution of a $5 \mu \mathrm{g}$ dietary dose of tributyltin $\left({ }^{113} \mathrm{Sn}-\mathrm{TBT}\right)$ and methylmercury $\left(\mathrm{Me}^{203} \mathrm{Hg}\right)$ were studied over $42 \mathrm{~d}$ in the American plaice Hippoglossoides platessoides, using in vivo gamma counting, whole-body autoradiography, and a 2 -compartment model. The average retention efficiency of TBI was $42 \%$, compared with $88 \%$ for $\mathrm{MeHg}$. Both organometals were distributed to the entire body of the fish. Distribution proceeded at a faster rate for TBT, $95 \%$ of the steady state distribution being reached within 5 to $10 \mathrm{~d}$, compared with 29 to $41 \mathrm{~d}$ for $\mathrm{MeHg}$. Elimination of TBT was characterised by half-life values ranging from 15 to $77 \mathrm{~d}$. Absorption of dietary TBT from the intestinal lumen appears to be limited by its molecular size, whereas its fast translocation rate in the body of fish might be related to specific properties of the intestinal epithelium-blood interface or to cotransport with lipids. Our data also indicated that butyltins in the viscera were partitioned between 2 kinetically distinct pools; one that was eliminated rapidly and one that was stored or eliminated at a very slow rate, probably as a consequence of TBT metabolism. The overall biomagnification factor for the transfer of TBT from sediments to benthic invertebrates to the American plaice may be $>1$. This indicates that the trophic transfer of sedimentary TBT in the marine benthic food web is potentially significant.
\end{abstract}

KEY WORDS: Tributyltin - Methylmercury - Food - Uptake Pharmacokinetics Fish - American plaice . Benthos Food web

\section{INTRODUCTION}

Tributyltin (TBT) is a highly toxic organometallic biocide used in antifouling paints (Fent 1996). While most research work published on TBT in marine biota concerns its bioaccumulation via water, little is known about its trophic transfer in aquatic food chains. A way to investigate mechanisms governing the fate of a given chemical in biota is to compare its behaviour with that of a related chemical for which uptake, distribution, and elimination mechanisms are known. Methylmercury (MeHg), another organometallic compound, has been extensively studied in these respects.

•E-mail: rouleauc@dfo-mpo.gc.ca
MeHg is biomagnified in food chains (Clarkson 1992) as a result of the combination of 2 factors. First, dietary $\mathrm{MeHg}$ is efficiently accumulated by predators, because this molecule easily crosses biological barriers (Boudou et al. 1991) and has a high affinity for thiol groups of biological tissues (Clarkson 1994). The second factor is the very long biological half-life of $\mathrm{MeHg}$ (Trudel \& Rasmussen 1997), which is due to the stability of the $\mathrm{Hg}-\mathrm{C}$ bond in biological media (Rabenstein $1978 \mathrm{a})$

TBT, like MeHg, is lipophilic and has a strong affinity for biological ligands (Laughlin et al. 1986. Musmeci et al. 1992). Considering this chemical kinship, the behaviour of dietary TBT and $\mathrm{MeHg}$ in living organisms can be expected to show some similarities. 
In a study of the pharmacokinetics of dietary TBT and $\mathrm{MeHg}$ over $48 \mathrm{~h}$ in the starfish Leptasterias polaris (Rouleau et al. 1995), we found that both organometals were more uniformly distributed in the body compared to inorganic $\mathrm{Hg}$ and $\mathrm{Sn}$, an indication of the similarity of their amphiphilicity. However, the rate of TBT distribution between organs was much slower than that of $\mathrm{MeHg}$, a result that seemed to be related to significant quantitative differences in properties like molecular structure, lipophilicity, and binding patterns. It is not known how the fate of dietary TBT would compare to that of $\mathrm{MeHg}$ in organisms other than starfish. The fact that TBT is readily metabolised in organisms like fish and crustaceans suggests that the long-term biomagnification of TBT is not as significant as for $\mathrm{MeHg}$ and organochlorine pollutants (Fent 1996). However, recent monitoring results showed that TBT may be biomagnified by various marine organisms (Takahashi et al. 1997, and references therein), indicating that the trophic transfer of this organometal needs to be investigated in more detail.

In this paper, we report the results of a $42 \mathrm{~d}$ experiment on the pharmacokinetics and tissue distribution of a single dietary dose of radiolabelled ${ }^{113} \mathrm{Sn}$-TBT and $\mathrm{Me}^{203} \mathrm{Hg}$ in the American plaice Hippoglossoides platessoides (order Pleuronectiformes, family Pleuronectidae). This benthic flatfish species is common on both sides of the North Atlantic, lives on fine sand or mud bottoms, and feeds on polychaete worms, mysids, amphipods, echinoderms, and bivalve molluscs. It is also known that flatfish constitute an important part of the diet of larger fish and some marine mammals (Scott \& Scott 1988). Study of the fate of dietary MeHg and TBT in such a marine benthic organism is of interest because organometals can be remobilised from the sediments by endobenthic organisms and transferred to epibenthic detritivores and predators long after contamination has ceased (Fowler 1982). Actually, the correlation often observed between the concentration of organometallic contaminants in benthic animals and in the sediments indicates that the latter can be the main source of these pollutants to the benthic food web (Fowler 1982, Bryan \& Langston 1992, Francesconi \& Lenanton 1992, Kannan et al. 1998). TBT has been found to persist for years once buried into the sediments (Adelman et al. 1990, de Mora et al. 1995), which are thus a potentially significant long-term source of this organometal to infaunal organisms constituting the lower trophic levels of benthic food chains. Though sediment-dwelling polychaete worms and deposit-feeding bivalves efficiently accumulate and concentrate sedimentary TBT (Bryan \& Langston 1992, and references therein), the trophic transfer of TBT and its fate in a benthic predatory fish of intermediate trophic level have never been studied.

\section{MATERIALS AND METHODS}

Specimens. American plaice were caught in the St. Lawrence Estuary in October 1995 by bottom trawling and thereafter kept in $2000 \mathrm{l}$ tanks supplied with aerated filtered flowing seawater, under conditions of natural photoperiod and ambient temperature $\left(5\right.$ to $\left.10^{\circ} \mathrm{C}\right)$. Fish were fed twice a week with a ration of chopped capelin representing $2.5 \%$ of the body weight. Once every $3 w k$, fish received in-house prepared capelinbased food pellets supplemented with vitamins (Provencher et al. 1995)

The experiment was performed in June and July 1996. Six gravid females, weighing $355 \pm 80 \mathrm{~g}$, were housed individually in $60 \mathrm{l}$ aquaria supplied with flowing seawater maintained at 5 to $6^{\circ} \mathrm{C}$. Fish were allowed to acclimatise to experimental conditions for $1 \mathrm{wk}$. They were fed as mentioned above during this period and throughout the experiment. One fish died because of a technical failure causing its aquarium to empty during the night.

Preparation and administration of contaminated food. Radioactive tributyltin and methylmercury were prepared from commercially available ${ }^{113} \mathrm{Sn}$ (IV) (92.5 MBq $\mathrm{mg}^{-1}$, New England Nuclear) and inorganic ${ }^{203} \mathrm{Hg}(\mathrm{II})$ (7.0 MBq $\mathrm{mg}^{-1}$. Amersham) according to Rouleau (1998) and Rouleau \& Block (1997), respectively. Chemical purity of both radioactive organometals was more than $98 \% .{ }^{113} \mathrm{Sn}$-TBT was dissolved in hexane and $\mathrm{Me}^{203} \mathrm{Hg}$ in $5 \mathrm{mM} \mathrm{Na}_{2} \mathrm{CO}_{3}$. One day before the beginning of the experiment, contaminated food was prepared by adding both radioactive organometals to $7-8 \mathrm{~g}$ of supplemented fish food (Provencher et al. 1995) in order to achieve concentrations of $5 \mathrm{\mu g}$ Sn $\mathrm{g}^{-1}$ as TBT and $5 \mu \mathrm{g} \mathrm{Hg} \mathrm{g}^{-1}$ as MeHg. ${ }^{113} \mathrm{Sn}$-TBT was diluted with non-radioactive TBT to have a specific activity of $35 \mathrm{kBq} \mathrm{g}^{-1}$ food, a level similar to that of radioactive $\mathrm{Me}^{203} \mathrm{Hg}$. After a 5 min manual homogenisation, the contaminated food was moulded in small balls weighing $0.5 \pm 0.1 \mathrm{~g}$ and kept at $4^{\circ} \mathrm{C}$

On Day 0 , the fish were anaesthetised by placing them in seawater containing $100 \mathrm{mg} \mathrm{l}^{-1}$ of tricaine (MS222) for 5 min. They then received 2 balls of contaminated food, which were gently pushed into the stomach with a glass rod. Radioactivity was measured immediately after feeding (see below) and the fish were returned to their aquarium. In a separate experiment, 6 additional fishes received inorganic ${ }^{203} \mathrm{Hg}$ (II) with their food, according to the above protocol.

Gamma counting. We repeatedly monitored ${ }^{113} \mathrm{Sn}$ and ${ }^{203} \mathrm{Hg}$ activities in each fish over $42 \mathrm{~d}$ with in vivo gamma counting. We used a 3 inch (ca $76 \mathrm{~mm}$ ) NaI(Tl) gamma detector (Canberra-Packard) fitted into a $2 \mathrm{~cm}$ thick cylindrical $\mathrm{Pb}$ shield with a $0.6 \mathrm{~cm}$ thick copperbrass inside lining. The detector-shield assembly was 
Fig. 1 Hippoglossoides platessoides. Location of viscera and gonads (solid lines) in female American plaice and sites of radioactivity measurement (dotted areas). The size of the latter is to scale relative to the average size of fish

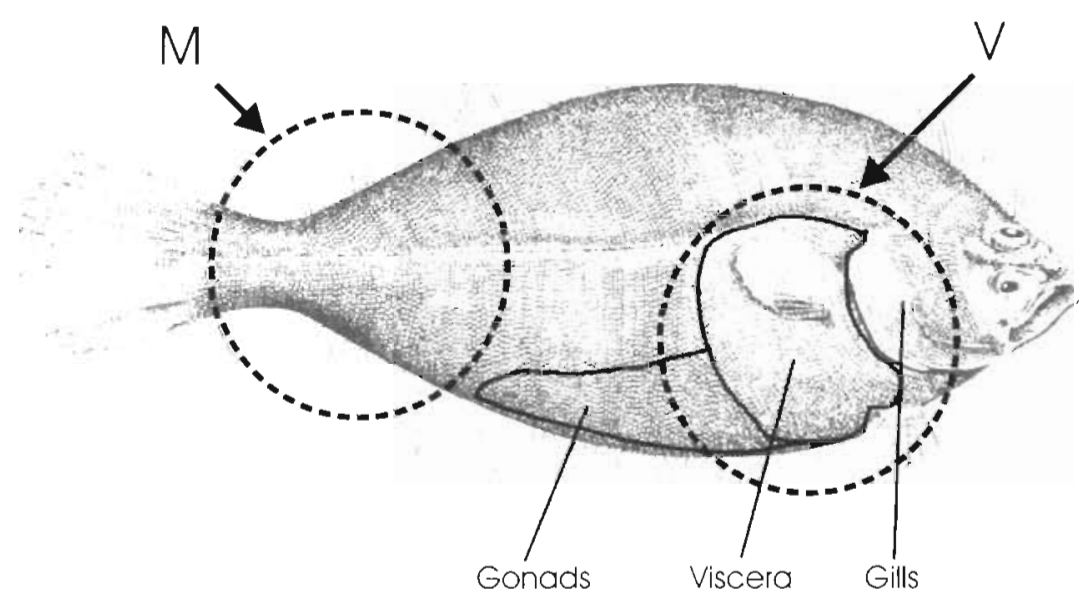

At the end of the experiment, fish were submitted to lethal anaesthesia. They were dissected, tissues and organs collected were placed in a $35 \mathrm{~mm}$ or a $60 \mathrm{~mm}$ Petri dish, depending on their size, weighed, and their radioactivity measured. If necessary, tissue samples were roughly homogenised and spread over the whole surface of the dish. Preliminary tests with radioisotope standards showed that activities measured varied little with the size of the Petri dish. Data obtained were used to calculate the percentage of ${ }^{113} \mathrm{Sn}$ and ${ }^{203} \mathrm{Hg}$ body burden represented by each organ and tissue. The concentration index, $I_{C}$, was then calculated with:

$$
I_{\mathrm{C}}=\frac{\% \text { of body burden }}{\% \text { of body weight }}=\frac{\left[{ }^{113} \mathrm{Sn} \text { or } \mathrm{Hg}\right] \text { in tissue }}{\left.\right|^{113} \mathrm{Sn} \text { or } \mathrm{Hg} \text { ] in whole body }}
$$

$I_{C}$ represents the ratio of isotope concentration in a given tissue over the average whole-body concentration. If $I_{C}>1$, then the tissue is enriched compared to the average concentration.

Whole-body autoradiography. Additional fish were used for whole-body autoradiography, a technique that allows visualisation of the fine-scale tissue distribution of radiolabelled compounds in thin cryosections of a whole animal (Ullberg et al. 1982). Due to technical limitations, fish used were smaller, weighing ca $50 \mathrm{~g}$. They were given $0.5 \mathrm{~g}$ of food contaminated with TBT or $\mathrm{MeHg}$, and 2 individuals were used for each organometal. Seven days after feeding, the fish were collected, embedded in a carboxymethylcellulose gel, rapidly frozen and sectioned on tape $(20 \mu \mathrm{m}$ thick sections) at $-20^{\circ} \mathrm{C}$ with a specially designed cryomicrotome (Jung Cryomacrocut, Leica). Finally, freeze-dried sections were applied to a X-ray film $\left({ }^{3} \mathrm{H}\right.$-Hyperfilm for ${ }^{1 / 3} \mathrm{Sn}$ and AGFA Structurix for ${ }^{203} \mathrm{Hg}$ ) for 3 to $6 \mathrm{mo}$, at $-20^{\circ} \mathrm{C}$.

Kinetic model. We previously showed that the fate of dietary $\mathrm{MeHg}$ in fish can be accurately described with a 3-compartment caternary model, the first compartment being the gut, the second one being liver, kidney, mean coefficient of variation found was $2 \%$. 
spleen, blood and gills, and the third one being constituted by the rest of the body (muscle, fins, bones, skin, head) (Oliveira Ribeiro et al. unpubl.). In the present study, it was obviously not possible to measure activity in compartments 1 and 2 separately. These compartments were then considered as a single one and the above model was simplified to:

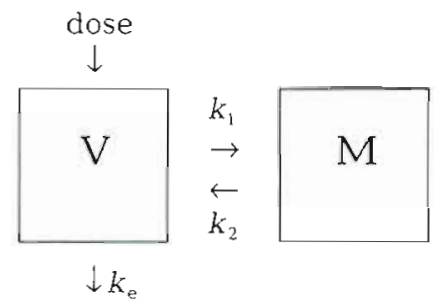

$\mathrm{V}$ and $\mathrm{M}$ correspond to areas shown in Fig. 1. $\mathrm{M}$ is assumed to be representative of the rest of body, according to the assumption of linear and instantaneous distribution of a chemical within a compartment (Barron et al. 1990). First-order rate constants $k_{1}$ and $k_{2}$ characterise distribution kinetics between compartments. Rate constant $k_{\mathrm{e}}$ characterises the elimination, which for TBT and MeHg occurs through the hepatobiliar pathway (Giblin \& Massaro 1973, Olson et al. 1978, Fent 1996). If $k_{e}$ is small compared to the sum of $k_{1}$ and $k_{2}$, then the biexponential equations describing $\mathbf{V}$ and $\mathbf{M}$, the organometal contents of compartments $\mathbf{V}$ and M, can be written as (Rouleau et al. 1995):

$$
\begin{aligned}
& \mathbf{V}=\mathbf{V}_{\mathbf{0}} \mathrm{e}^{-k_{\mathrm{e}} t}+\mathbf{M}_{0} \mathrm{e}^{-\left(k_{\mathrm{e}}+\alpha\right) t} \\
& \mathbf{M}=\mathbf{M}_{\mathbf{0}}\left(\mathrm{e}^{-k_{\mathrm{e}} t}-\mathrm{e}^{-\left(k_{\mathrm{e}}+\alpha \cdot t\right)}\right)
\end{aligned}
$$

$\mathbf{V}_{0}$ and $\mathbf{M}_{0}$ represent the amount of the organometal dose assimilated in compartments $\mathrm{V}$ and $\mathrm{M}$, respectively, whereas $\alpha$ is $\left(k_{1}+k_{2}\right)$. The total amount of organometal retained in the body after the initial loss from defecation, $R E_{0}$ is the sum of $\mathbf{V}_{0}$ and $\mathbf{M}_{\mathbf{0}}$. If elimination of the organometal is negligible, i.e. $k_{e} \approx 0$, Eqs. (2) \& (3) are then reduced to monoexponential equations:

$$
\begin{gathered}
\mathbf{V}=\mathbf{V}_{0}\left(1-\mathrm{e}^{-\alpha t}\right)+R E_{0} \mathrm{e}^{-\alpha t} \\
\mathbf{M}=\mathbf{M}_{0}\left(1-\mathrm{e}^{-\alpha t}\right)
\end{gathered}
$$

Values of $\mathbf{V}_{0}, \mathbf{M}_{0}, R E_{0}, \alpha, k_{\mathrm{e}}$ and $\left(k_{\mathrm{e}}+\alpha\right)$ were calculated from experimental data by non-linear regression analysis with the software Statgraph ${ }^{\otimes}$.

\section{RESULTS}

\section{Pharmacokinetics and retention}

Typical data of ${ }^{113} \mathrm{Sn}$ and ${ }^{203} \mathrm{Hg}$ activities in $\mathrm{V}$ and $\mathrm{M}$ as a function of time are shown in Fig. 2. Activity sharply decreased 2 to $4 \mathrm{~d}$ after feeding as nonretained organometals were eliminated with faeces.
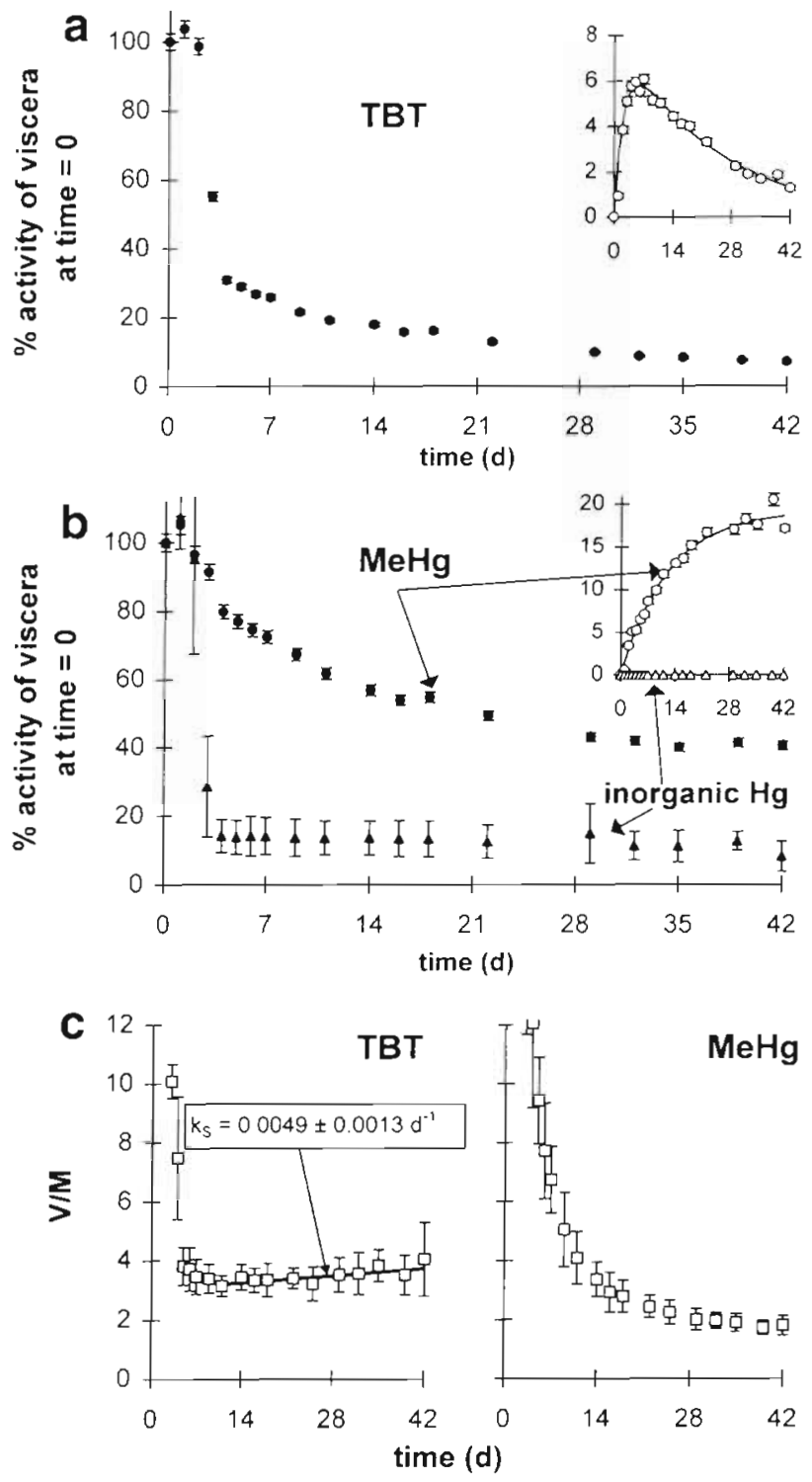

Fig. 2. Hippoglossoides platessoides. $(\mathrm{a}, \mathrm{b})$ Typical evolution of ${ }^{113} \mathrm{Sn}$ and ${ }^{203} \mathrm{Hg}$ activity over $42 \mathrm{~d}$ in compartment $\mathrm{V}(\bullet)$ and $M(O$, insets $)$ in a female American plaice that received $5 \mu \mathrm{g}$ of ${ }^{113} \mathrm{Sn}-\mathrm{TBT}$ and $\mathrm{Me}^{203} \mathrm{Hg}$ with food (fish \#8). Data standardised as a percentage of the activity measured in $\mathrm{V}$ at $t=0$. Bars represent the sum of statistical countung error and positioning error. Data from fish fed with food containing inorganic ${ }^{203} \mathrm{Hg}(\mathrm{II})$ are also shown ( $\Delta$ and $\Delta$, mean $\pm \mathrm{SD}, \mathrm{n}=6$ ). (c) Evolution of the ratio of activities measured in compartments $V$ and $M, V / M(\square$, mean $\pm S D, n=5)$. The fitted curve for TBT $(t=11$ to $42 d)$ and value of $k_{S}$ were obtained by linear regression analysis with Eq. $(6)\left(r^{2}=0.60, p<0.01\right)$

After defecation, the time course of ${ }^{113} \mathrm{Sn}$ content was biexponential (Eqs. 2 \& 3). This can be clearly seen for $M$; activity reached a maximum value after a few days and then declined steadily. On the other hand, the time course of ${ }^{203} \mathrm{Hg}$ activity in compartments $\mathrm{V}$ and $\mathrm{M}$ was monoexponential, indicating that elimination was neg- 
ligible for this experiment, and that kinetics can be quantified with Eqs. (4) \& (5). In fish fed with inorganic ${ }^{203} \mathrm{Hg}(\mathrm{II})$, it is noteworthy that only $15 \%$ of the activity was retained and that none of it was detected in $M$.

Values of rate constants $\alpha, \alpha+k_{e}$ and $k_{e}$ calculated from experimental data of compartment $M$ are shown in Table 1. The fit of regression curves with data is excellent, as shown by the high values of $r^{2}$. It can be seen that the distribution of ${ }^{203} \mathrm{Hg}$ from $\mathrm{V}$ towards $\mathrm{M}$, characterised by the rate constant $\alpha$, was much slower compared to ${ }^{113} \mathrm{Sn}$. Actually, the distribution process was completed at $95 \%$ within 5 to $10 \mathrm{~d}$ for TBT-fed fish, while this took 29 to $41 \mathrm{~d}$ for the other group. ${ }^{1 i 3} \mathrm{Sn}$ elimination was moderately fast but highly variable from one fish to another, biological half-life values ranging from 15 to $77 \mathrm{~d}$. Retention efficiency, $R E_{0}$, was calculated by extrapolating model curves to time 0 for both compartments and making corrections for counting geometry. The average value found for $\mathrm{MeHg}$ was twice that of TBT (Table 1).

According to our model, the ratio of the activities measured in the 2 compartments, V/Mi should decrease with time and tend toward a constant value equal to $\mathbf{V}_{\mathbf{0}} / \mathbf{M}_{\mathbf{0}}$ as distribution reaches a steady state, i.e. for such values of time $t$ so that the exponential term in Eqs. (2) to (5) containing rate constant $\alpha$ tends toward zero (Rouleau et al. 1995). However, in the TBT group V/M reached a minimum at Day 11 and then increased steadily (Fig. 2). This indicates that ${ }^{113} \mathrm{Sn}$ in $V$ was partitioned between 2 kinetically distinct pools, of which one was stored or eliminated at a rate too slow to be measured. This situation can be illustrated as follows

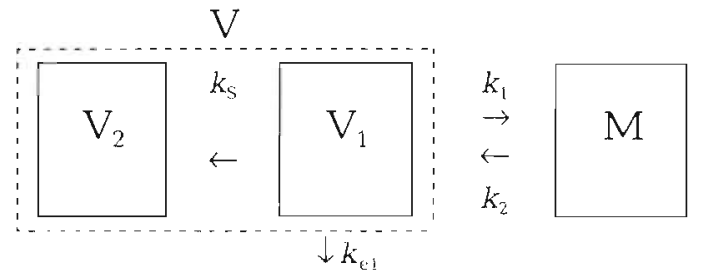

Rate constant $k_{\mathrm{S}}$ characterises the rate at which ${ }^{113} \mathrm{Sn}$ is transfered from $V_{1}$ to $V_{2}$, the 'storage' compartment. The link between this model and the one presented in the 'Material and methods' section is that rate constant $k_{\varepsilon}=k_{e 1}+k_{\mathrm{S}}$. As the activities of ${ }^{113} \mathrm{Sn}$ pools in $\mathrm{V}$ were measured simultaneously, it can be shown that $\mathbf{V} / \mathbf{M}$ will not reach a constant value as:

$$
\begin{gathered}
\mathbf{V} / \mathbf{M}=\left(\mathbf{V}_{0} / \mathbf{M}_{0}\right) \mathrm{e}^{k t} \text { or } \\
\ln (\mathbf{V} / \mathbf{M})=\ln \left(\mathbf{V}_{0} / \mathbf{M}_{0}\right)+k_{S} t
\end{gathered}
$$

The slope $k_{\mathrm{S}}$ of $\ln (\mathbf{V} / \mathbf{M})$ versus $t$ between Day 11 and 42 was significantly different from $0\left(\mathrm{r}^{2}=0.60, \mathrm{p}<0.01\right)$ (Fig. 2) and its value indicates that $-20 \%$ of the assimilated ${ }^{113} \mathrm{~S} n$ would be stored $\left(100 \times k_{\mathrm{S}} / k_{\mathrm{e}}\right)$.

\section{Tissue distribution}

Whole-body autoradiograms of fish sampled $7 \mathrm{~d}$ after feeding with radioactive TBT or $\mathrm{MeHg}$ are shown in Fig. 3. In the case of TBT, the distribution was quite uniform and reflected the completion of the distribution process. Gut tissues, gills, heart, kidney, spleen, liver and blood had a similar labelling. However, the gall bladder was more labelled. ${ }^{113} \mathrm{Sn}$ labelling of blood was much more important than in

Table 1 Hippoglossoides platessoides. Pharmacokinetic parameters measured after administration of a single dietary dose of ${ }^{113} \mathrm{Sn}-\mathrm{TBT}$ and $\mathrm{Me}{ }^{2 n 3} \mathrm{Hg}$ in the American plaice. Values $( \pm \mathrm{SE})$ of rate constants $\alpha,\left(\alpha+k_{e}\right)$, and $k_{\mathrm{e}}$ were calculated from activity data in compartment $M$, using nonlinear regression analysis with Eq. (3) for TBT and Eq. (5) for MeHg. Time needed for distribution to be completed at $95 \%, t_{0} 95 \%$ and biological half-life, $t_{0}$ s, were calculated with $2.996 / \alpha$ and $0.693 / k_{\mathrm{e}}$, respectively. Values

\begin{tabular}{|c|c|c|c|c|c|c|}
\hline TBT & $\begin{array}{l}R E_{0} \\
(\%)\end{array}$ & $\begin{array}{c}\alpha+k_{\mathrm{t}} \\
\left(\mathrm{d}^{-1}\right)\end{array}$ & $\begin{array}{l}t_{0.95 \alpha} \\
\text { (d) }\end{array}$ & $\begin{array}{c}k_{\mathrm{u}} \\
\left(\mathrm{d}^{-1}\right)\end{array}$ & $\begin{array}{l}t_{05} \\
\text { (d) }\end{array}$ & $r^{2}$ \\
\hline Fish \#6 & & $0.360 \pm 0.050$ & 9 & $0.022 \pm 0.003$ & 32 & 0.93 \\
\hline Fish \#8 & & $0.356 \pm 0.052$ & 10 & $0.047 \pm 0.005$ & 15 & 0.93 \\
\hline Fish \#11 & $42 \pm 7$ & $0.566 \pm 0.092$ & 5 & $0.019 \pm 0.003$ & 36 & 0.91 \\
\hline Fish \#12 & & $0.544 \pm 0.073$ & 6 & $0.009 \pm 0.002$ & 77 & 0.93 \\
\hline Fish \#13 & & $0.480 \pm 0.063$ & 6 & $0.017 \pm 0.002$ & 41 & 0.93 \\
\hline $\mathrm{MeHg}$ & $\begin{array}{l}R E_{0} \\
(\%)\end{array}$ & $\begin{array}{c}\alpha \\
\left(d^{-1}\right)\end{array}$ & (d) & $\begin{array}{c}k_{\mathrm{c}} \\
\left(\mathrm{d}^{-1}\right)\end{array}$ & (d) & $r^{2}$ \\
\hline Fish $\# 6$ & & $0.073 \pm 0.005$ & 41 & & & 0.98 \\
\hline Fish \#8 & & $0.083 \pm 0.006$ & 36 & & & 0.99 \\
\hline Fish \#11 & $88 \pm 8$ & $0.082 \pm 0.006$ & 36 & nd & nd & 0.98 \\
\hline Fish \#12 & & $0.103 \pm 0.005$ & 29 & & & 0.99 \\
\hline Fish \#13 & & $0.092 \pm 0.004$ & 33 & & & 0.99 \\
\hline
\end{tabular}
of retention efficiency, $R E_{0,}$ are means $\pm \mathrm{SD}$. nd: not determined, negligible elimination 


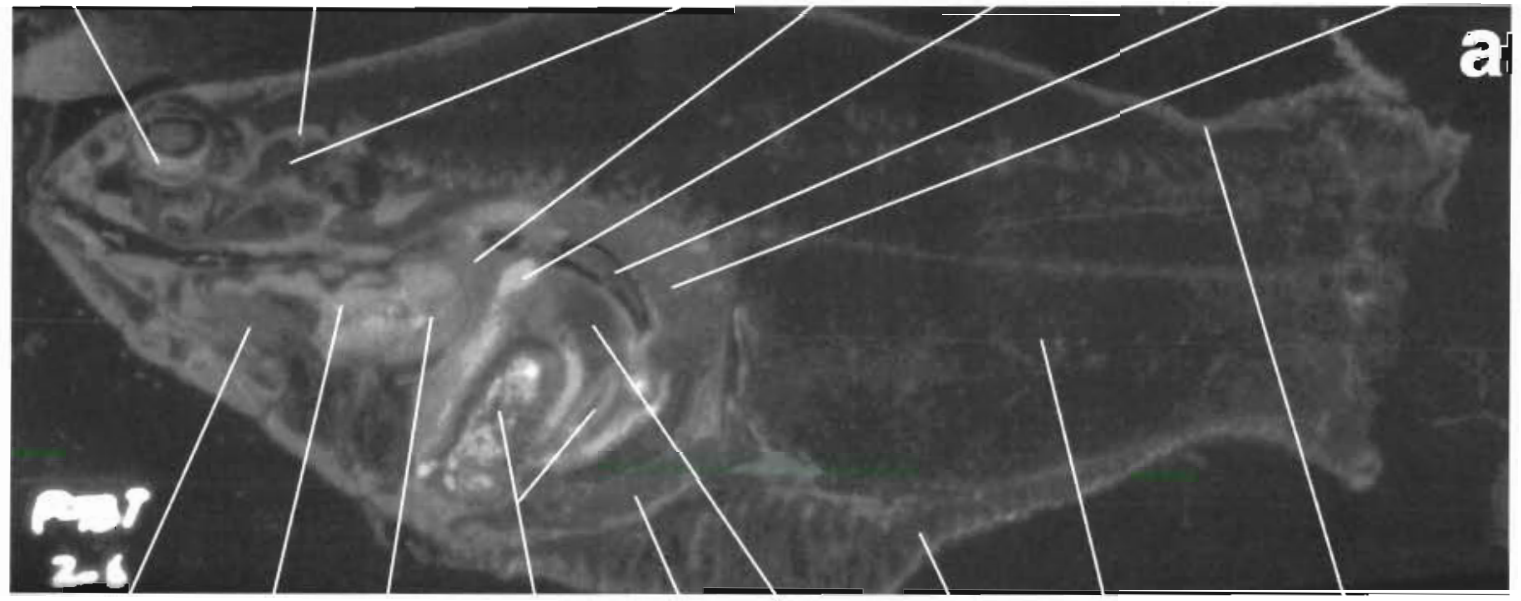

Gills Blood Heart Intestine Gonad Spleen Fin White muscle Red muscle

\section{Brain Liver Gall bladder Stomach Kidney Spleen Muscle}

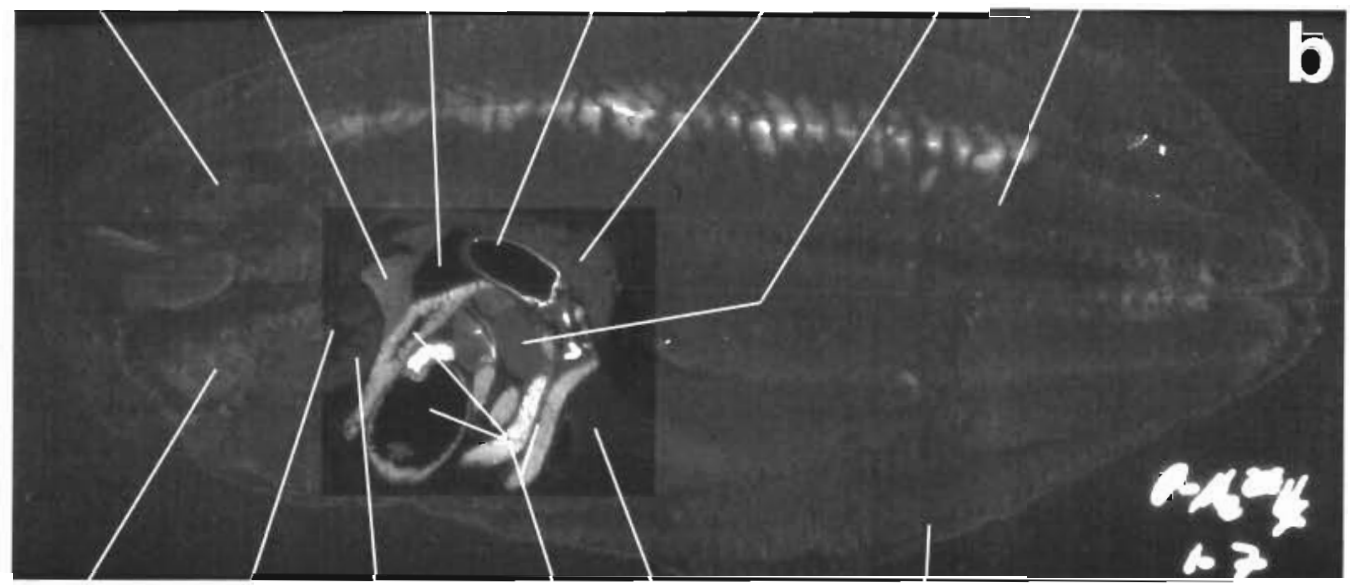

Gills

Blood Heart Intestine Gonad

Fin

Fig. 3. Hippoglossordes platessoides. Autoradiograms obtained 7 d after feeding with (a) ${ }^{113} \mathrm{Sn}-\mathrm{TBT}$ or (b) Me ${ }^{203} \mathrm{Hg}$. The contrast of the area around the central square in (b) has been enhanced

$\mathrm{Me}^{203} \mathrm{Hg}$-fed fish. Richly vascularised tissues, such as the eye choroid and red muscle tissues, had a labelling similar to that of blood. White muscle tissues had a lower but noticeable labelling. The cerebrospinal fluid surrounding the brain had a labelling similar to that of viscera, though the brain itself was not labelled. The labelling of intestinal lumen indicated the presence of TBT. The labelling of the stomachal lumen was due to damage to the uncoated ${ }^{3} \mathrm{H}$-Hyperfilm resulting from the direct contact of the tape at this location.

In MeHg-fed fish, the highest labelling was found in stomach and intestine walls, whereas their lumen was not labelled. The labelling of liver, kidney and spleen was important, but lower than in stomach and gut tissues. Blood had a very low labelling compared to heart muscle. The labelling of all other tissues, though much lower than in the viscera, was quite uniform. The bright band in white muscle is an artefact resulting from the packing of muscle tissue under the microtome knife during sectioning. The brain had a labelling similar to that of muscle. The strong gradient observed between the visceral organs and the rest of the body is in accordance with pharmacokinetic data, which indicated that the transfer of $\mathrm{MeHg}$ from viscera toward the rest of body was not in an advanced state after $7 \mathrm{~d}$. In fish fed with inorganic ${ }^{203} \mathrm{Hg}(\mathrm{II})$, the gut was the only tissue labelled (not shown). 

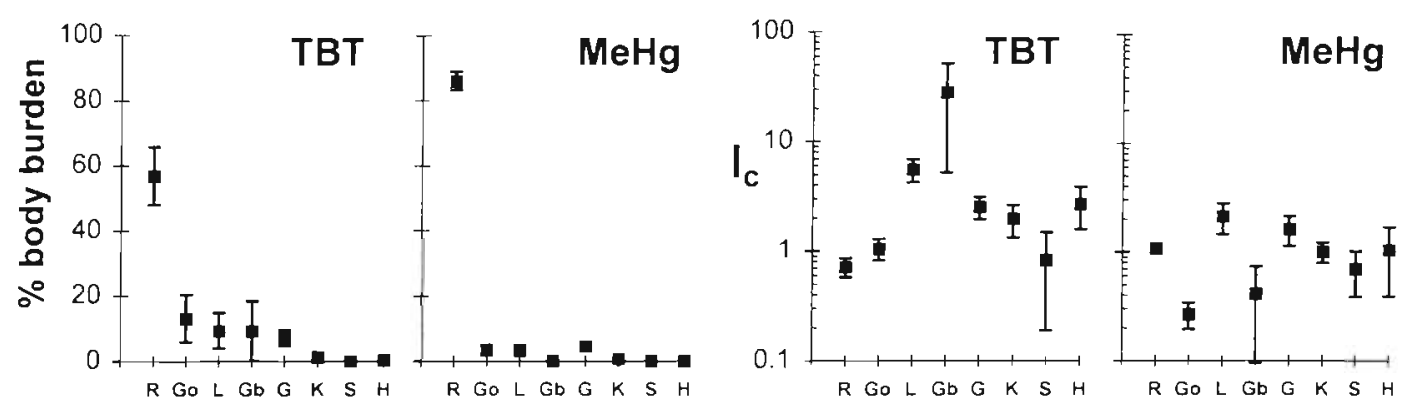

Fig. 4. Hippoglossoides platessoides. Percentage of ${ }^{113} \mathrm{Sn}$ and ${ }^{203} \mathrm{Hg}$ body burden and concentration index, $l_{(\cdot,}$ of various organs and tissues in fish dissected $42 \mathrm{~d}$ after the ingestion of ${ }^{113} \mathrm{Sn}-\mathrm{TBT}$ and Me ${ }^{203} \mathrm{Hg}$ with food $(\operatorname{mean} \pm \mathrm{SD}, \mathrm{n}=5$ ). $\mathrm{G}=\mathrm{gut}, \mathrm{Gb}=\mathrm{gall}$ bladder, $\mathrm{Go}=$ gonads, $\mathrm{H}=$ heart, $\mathrm{K}=$ kidney, $\mathrm{L}=$ liver, $\mathrm{R}=$ rest of body, $\mathrm{S}=$ spleen

Distribution data, \% body burden and $I_{C}$, obtained by dissecting the fish $42 \mathrm{~d}$ after feeding, are shown in Fig. 4. In TBT-fed fish, almost $60 \%$ of ${ }^{113} \mathrm{Sn}$ body burden was found in the rest of the body. Gonads, liver, and gall bladder accounted for 9 to $13 \%$ whereas the other tissues accounted for $\leq 1 \%$. Average values of $I_{\mathrm{C}}$ were 1 to 2 for the rest of body, gonads, spleen, gut, kidney and heart, 6 for the liver, and 28 for the gall bladder. From the latter data, it appears that the concentration of radioactive ${ }^{113} \mathrm{Sn}$ in the liver and the gall bladder at Day 42 was much higher relative to the other viscera, compared to what autoradiograms taken at Day 7 showed. In the case of $\mathrm{MeHg}$, for which pharmacokinetic data indicated that the distribution process was completed at that time, the rest of the body accounted for more than $85 \%$ of ${ }^{203} \mathrm{Hg}$ body burden, gonads, gut and liver for 3 to $5 \%$ each, and the other tissues for less than $1 \%$ each. Nevertheless, almost all $I_{\mathrm{C}}$ values were close to 1 , except those of gonads and gall bladder.

\section{DISCUSSION}

The advantage of in vivo gamma counting resides in the precise and repetitive measurements of radioactivity in a single animal that allow one to detect possible changes in distribution and elimination rates with more accuracy, e.g. distinguishing between mono- and biexponential kinetics. The anatomy of Pleuronectiformes fish is also advantageous as it renders possible the study of distribution kinetics between 2 different compartments without dissecting the specimens. Nondestructive sampling therefore reduces the number of fish sacrificed. Conditions of temperature and salinity in our aquaria were close to those prevailing in the natural habitat of this fish species to ensure that kinetics observed were as representative as possible of actual ones. Though anaesthesia may have stressed the fish, it is known that the net benefit of anaesthesia is positive, when used under proper conditions, as it reduces handling stress (Summerfelt \& Smith 1990)
The interpretation of pharmacokinetics data acquired from total radioactivity measurements may be biased if metabolism of the parent chemical occurs (Gibaldi \& Perrier 1982). TBT is known to be metabolised quite rapidly in fish, crustaceans, and mammals (Fent 1996). Nevertheless, initial absorption and distribution processes discussed below are likely to be representative of TBT behaviour, as TBT is mostly metabolised in the liver (Fent 1996), after the compound had been absorbed from food and transferred to the blood. However, the elimination process needs to be discussed with the idea in mind of the possible occurrence of other butyltin species and inorganic Sn. Our data (Fig. 2) clearly showed that dietary inorganic ${ }^{203} \mathrm{Hg}(\mathrm{II})$ was poorly retained and not transferred at all to compartment $M$. Thus, the high assimilation and the transfer of radioactivity to compartment $M$ observed in $\mathrm{Me}^{203} \mathrm{Hg}$-dosed fish are probably representative of $\mathrm{MeHg}$ actual behaviour.

\section{Absorption and distribution}

Uptake of dietary contaminants in fish proceeds in 2 steps: the contaminants are first absorbed from the intestinal lumen into the epithelium, and then transferred to blood from which they are distributed to the other tissues (Barron 1995). Our results (Table 1) showed striking differences between MeHg and TBT in this respect. First, the values of $R E_{0}$ indicate that the apparent rate of absorption of $\mathrm{MeHg}$ from the intestinal lumen was faster than for TBT. In contrast, the rate of distribution of TBT from $V$ to $M$ was much faster, as shown by the value of rate constant $\alpha$. High ${ }^{113} \mathrm{Sn}$ concentration in blood was also seen in autoradiograms from TBT-fed fish sampled $7 \mathrm{~d}$ after feeding. It thus clearly appears that the transfer of TBT from the intestinal epithelium towards blood was much easier than that of $\mathrm{MeHg}$. As both organometals were administered simultaneously, they were submitted to the same conditions and driving forces within a given fish, 
like chemical conditions in blood and intestine, transit rate of food along the gut, and rate of blood flow. Thus, the only factors that can explain the observed differences are related to the ability of these compounds to cross the biological barriers encountered at the Iumenepithelium and the epithelium-blood interfaces.

The transport of organometals through biological membranes appears to be governed by their strong binding to thiol groups and their capacity to form neutral species with $\mathrm{Cl}^{-}$and $\mathrm{OH}^{-}$that can diffuse passively through cellular membranes (Pelletier 1995). In biological media, MeHg is almost entirely bound to thiol groups (Rabenstein 1978b) and the simple diffusion of neutral $\mathrm{MeHg}$ species probably plays a small role (Ballatori 1991). Actually, the transport of $\mathrm{MeHg}$ across cell membrane appears to be mediated by glutathione and other small mobile thiol ligands (Richardson \& Murphy 1975. Ballatori 1991). Such a carrier-mediated transport is not known to occur with TBT (Laughlin 1996). A model developed instead for trialkyltin compounds is based on the passive diffusion of neutral species (Pelletier 1995, and references therein). Dietary absorption efficiency of neutral hydrophobic chemicals in fish correlates well with the chemicals' molecular volume (Niimi \& Oliver 1988). The molecular volume of TBT chloride and hydroxide lies between 26 and $27 \mathrm{~nm}^{3}$ (Bondi 1964). This is in the range of values $(0.25$ to $0.30 \mathrm{~nm}^{3}$ ) for which dietary absorption efficiency of hydrophobic chemicals was observed to decrease rapidly from 60 to $10 \%$ (Nimi \& Oliver 1988), indicating that the size of the TBT molecule may limit its transfer across the lumen-epithelium interface. However, other factors that cannot be excluded at present might play a role, such as a rate-limiting dissolution of this very hydrophobic chemical from the food source (Barron 1995) and its interactions with membrane proteins (Pelletier 1995).

The possible mechanisms underlying the fast transfer of TBT across the epithelium-blood interface can only be speculated upon. The membrane properties of this interface relative to those of the lumen-epithelium interface might be different. Another possibility is the processing of hydrophobic TBT molecules into very low density lipoproteins followed by transport together with them across the interface (Barron 1995). Further work on the partitioning of TBT among the various components of intestine epithelial cell.s and blood will be needed to understand mechanisms governing its passage through this interface.

\section{Elimination}

The pharmacokinetics of dietary MeHg in the American plaice is in accordance with previous reports of its very slow elimination rate in fish $\left(t_{05}=200\right.$ to $\left.700 \mathrm{~d}\right)$ (Jarvenpää et al. 1970, Pentreath 1976, Trudel \& Rasmussen 1997). Values of $k_{\mathrm{e}}$ measured for TBT-fed fish. were similar to those reported for juvenile red sea bream Pagrus major and starry flounder Platichthys stellatus (Yamada et al. 1994, Meador 1997). TBT is readily metabolised in fish, mostly in the liver, and excretion of metabolites is almost exclusively biliar (Fent 1996). The labelling of intestinal content observed in autoradiograms (Fig. 3) and the high values of $I_{C}$ of liver and gall bladder (Fig. 4) indicate that the hepato-biliar pathway is the main metabolism and excretion route of butyltins in American plaice as well. Though we cannot identify which ${ }^{113} \mathrm{Sn}$-butyltin species were exchanged between compartments $V$ and $M$, it is clear from our results that they were very mobile; after the maximum activity was achieved in compartment $M$, it immediately began to decrease, indicating that ${ }^{113} \mathrm{Sn}$-butyltins were likely transterred back to compartment $\mathrm{V}$.

Our data also showed that ${ }^{113} \mathrm{Sn}$-butyltins in compartment $V$ were partitioned between 2 kinetically distinct pools. This may be related to the 2 -step metabolism process of TBT, the first one being the hydroxylation of the carbon chain by the cytochrome P-450 dependent monooxygenase system, which is followed by spontaneous dealkylation of the hydroxy derivatives produced (Fent 1996). The latter can be conjugated to sulphate and glucuronic acid moieties prior to dealkylation and these highly polar conjugates are likely to be rapidly eliminated (Lee 1996). On the other hand, dealkylation products (dibutyltin, monobutyltin, inorganic tin) might constitute the stored or slowly excreted pool as their concentrations in tissues have been observed to increase as TBT metabolism progresses (Lee 1996).

\section{Environmental significance of the trophic transfer of TBT}

Assessment of the food chain transfer of toxic chemicals under a given exposure regime is one of the main concerns in ecotoxicology, and kinetic-based models are often used for that purpose (Landrum et al. 1992). Equilibrium whole-body accumulation of a chemical in a predator can be calculated from kinetic data with a simple 1-compartment model, expressed as (Landrum et al. 1992):

$$
C_{\mathrm{P}}=C_{\mathrm{F}} \cdot R E_{0} \cdot k_{\text {in }} / k_{\mathrm{e}}=C_{\mathrm{F}} \cdot B M F
$$

where $C_{\mathrm{P}}$ and $C_{\mathrm{F}}$ represent the whole-body concentrations of the chemical in the predator and in its food, respectively, rate constant $k_{1 n}$ is the rate of food consumption ( $1 \%$ of body weight $\mathrm{d}^{-1}$; Horwood et al. 
1989), and $B M F$ is the biomagnification factor. If $B M F>1$, then the equilibrium whole-body-averaged concentration of the chemical will be higher in the predator than in its food. To calculate the BMF of TBT and $\mathrm{MeHg}$ for the American plaice, we used our experimental data (Table 1) and values of $k_{\mathrm{e}}$ for $\mathrm{MeHg}$ in flatfish given by Jarvenpää et al. (1970) and Pentreath (1976) which comprised between 0.001 and $0.004 \mathrm{~d}^{-1}$. $B M F$ calculated this way ranges from 0.1 to 0.5 for TBT and from 2 to 9 for $\mathrm{MeHg}$, values similar to those previously reported from the ratio of organometal concentration in various marine fish species over that measured in their food (Francesconi \& Lenanton 1992, Takahashi et al. 1997).

In order to evaluate the environmental significance of the trophic transfer of sedimentary TBT in the benthic food web, we modelled TBT equilibrium concentration for American plaice belonging to a given benthic community for which sediments were considered the only TBT source. If direct uptake from water and sediment is not considered in the first instance, it can be shown from Eq. (7) that TBT concentration in a predator at the $n$th trophic level, $C_{\mathrm{P}_{n^{\prime}}}$ is

$$
C_{\mathrm{P}_{n}}=[\mathrm{S}] \cdot B M F_{1} \cdot B M F_{2} \cdot \ldots \cdot B M F_{n}
$$

where [S] is the concentration of TBT in the sediment. Langston et al. (1987) found an average BMF of 5 for the transfer of TBT from sediments to benthic invertebrates constituting the diet of flatfish. The overall $B M F$ for the transfer of TBT from sediments to benthic invertebrates and subsequently to the American plaice $\left(B M F_{\text {benthos }} \cdot B M F_{\text {plaice }}\right)$ would be therefore in the range 0.5 to 2.5 , indicating that the trophic transfer of sedimentary TBT in the benthic food web is potentially significant.

Acknowledgements. This work was supported by the Toxic Chemicals Program of the Canadian Department of Fisheries and Oceans and the Swedish Foundation for Strategic Environmental Research. The authors gratefully acknowledge the useful comments of the anonymous reviewers which helped us to improve the original manuscript, and the technical assistance of Luc Beaudin, Julie Bolduc, Agneta Boström, and Paul Robichaud.

\section{LITERATURE CITED}

Adelman D, Hinga KR, Pilson MEQ (1990) Biogeochemistry of butyltins in an enclosed marine ecosystem. Environ Sci Technol 24:1027-1032

Ballatori N (1991) Mechanism of metal transport across liver cell plasma membranes. Drug Metab Rev 23:83-132

Barron MG (1995) Bioaccumulation and bioconcentration in aquatic organisms. In: Hoffman DJ, Rattner BA, Burton GA Jr, Cairns J Jr (eds) Handbook of ecotoxicology. Lewis Publishers, Boca Raton, FL, p 652-666

Barron MG, Stehly GR, Hayton WL (1990) Pharmacokinetic modeling in aquatic animals. I. Models and concepts
Aquat Toxicol 18:61-86

Bondi A (1964) van der Waals volume and radii. J Phys Chem 68:441-451

Boudou A, Delnomdedieu M, Georgescauld D, Ribeyre F, Saouter E (1991) Fundamental roles of biological barriers in mercury accumulation and transfer in freshwater ecosystems (analysis at organism, organ, cell and molecular levels). Water Air Soil Pollut 56:807-821

Bryan GW, Langston WJ (1992) Bioavailability, accumulation and effects of heavy metals in sediments with special reference to United Kingdom estuaries: a review. Environ Pollut 76:89-131

Clarkson TW (1992) Mercury: major issues in environmental health. Environ Health Perspect 100:31-38

Clarkson TW (1994) The toxicology of mercury and its compounds. In: Watias CJ, Huckabee JW (eds) Mercury pollution: integration and synthesis. Lewis Publishers, Boca Raton, FL, p 631-642

de Mora SJ, Stewart C, Phillips D (1995) Sources and rate of degradation of tri(n-butyl)tin in marine sediments near Auckland, New Zealand. Mar Pollut Bull 30:50-57

Fent K (1996) Ecotoxicology of organotin compounds. Crit Rev Toxicol 26:1-117

Fowler SW (1982) Biological transfer and transport processes. In: Kullenberg $G$ (ed) Pollutant transfer and transport in the sea, Vol 2. CRC Press, Boca Raton, FL, p 1-65

Francesconi KA, Lenanton RCJ (1992) Mercury contamination in a semi-enclosed marine embayment: organic and inorganic mercury content of biota, and factors influencing mercury levels in fish. Mar Environ Res 33:189-212

Gibaldi M, Perrier D (1982) Pharmacokinetics. Marcel Dekker Inc, New York

Giblin FJ, Massaro EJ (1973) Pharmacodynamics of methyl mercury in the rainbow trout (Salmo gairdneri): tissue uptake, distribution and excretion. Toxicol Appl Pharmacol 24:81-91

Horwood JW, Walker MG, Witthames P (1989) The effect of feeding levels on the fecundity of plaice (Pleuronectes platessa). J Mar Biol Assoc UK 69:81-92

Jarvenpää T, Tillander M, Miettinen JK (1970) Methylmercury: half-time of elimination in flounder, pike and eel, Suom Kemistilehti B 43:439-442

Kannan K, Smith RG Jr, Lee RF, Windom HL, Heitmuller PT, Macauley JM, Summers JK (1998) Distribution of total mercury and methyl mercury in water, sediment, and fish from South Florida estuaries. Arch Environ Contam Toxicol 34:109-118

Landrum PF, Lee H II, Lydy MJ (1992) Toxicokinetics in aquatic systems: model comparison and use in hazard assessment. Environ Toxicol Chem 11:1709-1725

Langston WJ, Burt GR, Zhou M (1987) Tin and organotin in water, sediment, and benthic organisms of Poole Harbour. Mar Pollut Bull 18:634-639

Laughlin RB Jr (1996) Bioaccumulation of TBT in aquatic organisms. In: Champ MA, Seligman PF (eds) Organotin: environmental fate and effects. Chapman \& Hall, London, p 331-355

Laughlin RB Jr, Guard HE, Coleman WM (1986) Tributyltin in seawater: speciation and octanol-water partition coefficient. Environ Sci Technol 20:201-204

Lee RF (1996) Metabolism of tributyltin by aquatic organisms. In: Champ MA, Seligman PF (eds) Organotin: environmental fate and effects. Chapman \& Hall, London, p 369-382

Meador JP (1997) Comparative toxicokinetics of tributyltin in five marine species and its utility in predicting bioaccumulation and acute toxicity. Aquat Toxicol 37:307-326 
Musmeci MT, Madiona G, Lo Guidice MT, Silvestri A, Ruisi G. Barbieri R (1992) Interactions of organotins with biological system. Appl Organomet Chem 6:127-138

Nimi AJ, Oliver BG (1988) lnfluence of molecular weight and molecular volume on dietary absorption efficiency of chemicals by fishes. Can J Fish Aquat Sci 45:222-227

Olson KR, Squibb KS, Cousins RJ (1978) Tissue uptake, subcellular distribution, and metabolism of ${ }^{14} \mathrm{CH}_{3} \mathrm{HgCl}$ and $\mathrm{CH}_{3}{ }^{203} \mathrm{HgCl}$ by rainbow trout (Salmo gairdnern). J Fish Res Bd Can 35:381-390

Pelletier E (1995) Environmental organometallic chemistry of mercury, tin, and lead: present status and perspectives. In: Tessier A, Turner DR (eds) Metal speciation and bioavailability in aquatic systems. John Wiley and Sons, Chichester, p 103-1.48

Pentreath RJ (1976) The accumulation of mercury from food by the plaice Pleuronectes platessa L. J Exp Mar Biol Ecol 25:51-65

Provencher L, Bryl P, Gendron A, Roy F, Boyer J (1995) Essais d'alimentation de la morue franche (Gadus morhua). Rapp Tech Ind Sci Halieut Aquat 228

Rabenstein DL (1978a) The chemistry of methylmercury toxicology. J Chem Educ 55:292-296

Rabenstein DL (1978b) The aqueous solution chemistry of methylmercury and its complexes. Accounts Chem Res 11: 100-107

Richardson R, Murphy S (1975) Effect of glutathione depletion on tissue deposition of methylmercury in rats. Toxicol Appl Pharmacol 31:505-519

Editorial responsibility: Scott Fowler (Contributing Editor), Monaco
Rouleau C (1998) Synthesis of radioactive ${ }^{113} \mathrm{Sn}$-tributyltin of high specific activity for use in environmental fate studies. Appl Organomet Chem 12:435-438

Rouleau C, Block M (1997) Fast and high-yield synthesis of radioactive $\mathrm{CH}_{3}{ }^{203} \mathrm{Hg}(\mathrm{II})$. Appl Organomet Chem 11: $751-753$

Rouleau C, Pelletier E, Tjälve H (1995) Distribution kinetics of trophic single doses of methylmercury, tributyltin and corresponding inorganic ions in the starfish Leptasterias polaris. Mar Ecol Prog Ser 124:143-158

Scott WB, Scott MG (1988) Atlantic fishes of Canada. Can Bull Fish Aquat Sci 219

Summerfelt RC, Smith LS (1990). Anesthesia, surgery, and related techniques. In: Schreck CB, Moyle PB (eds) Methods for fish biology. American Fisheries Society, Bethesda, MD, p 223-227

Takahashi S, Tanabe S, Kubodera T (1997) Butyltin residues in deep-sea organisms collected from Suruga Bay, Japan. Environ Sci Technol 31:3103-3109

Trudel M, Rasmussen JB (1997) Modeling the elimination of mercury by fish. Environ Sci Technol 31:1716-1722

Ullberg S, Larsson B, Tjälve $H$ (1982) Autoradiography. In: Gleen HJ (ed) Biological applications of radiotracers. CRC Press, Boca Raton, FL, p 56-108

Yamada H, Tateishi M, Takayanagi K (1994) Bioaccumulation of organotin compounds in the red sea bream $\left(\mathrm{Pa}_{\mathrm{a}}\right.$ grus major) by two uptake pathways: dietary uptake and direct uptake from water Environ Toxicol Chem 13: 1415-1422

Submitted: March 16, 1998; Accepted: July 2, 1998 Proofs received from author(s): August 27, 1998 